\title{
RURAL EMIGRATION TO INTERNATIONAL DESTINATIONS AND RETURN: A PERSPECTIVE FROM IRELAND
}

\author{
Mary CAWLEY \\ Whitaker Institute and School of Geography and Archaeology, National University of Ireland Galway. \\ mary.cawley@nuigalway.ie
}

\begin{abstract}
Summary
This article aims to contribute to a better understanding of international emigration from and return to rural areas using evidence from Ireland. The paper introduces key concepts relating to migration and return more generally. The results of interviews with forty-six returned migrants, who were interviewed in 2011 and 2013, are then discussed. All emigrants spent at least one year resident overseas and spent at least one year resident in Ireland following return. The evidence reveals the continued influence of economic and social factors on emigration. Emigration and access to employment were facilitated by family and friends overseas, among the lower skilled, whilst the more highly qualified used agencies and advertisements. Most migrants lived within transnational frameworks; they maintained regular contact with family at home and many visited home at least once annually. These links functioned as sources of information about opportunities in Ireland. Most returned to employment; however, reuniting with family was a key motivation for return coupled with memories of an idyllic countryside. The experience following return did not always meet expectations and some returnees emigrated again.
\end{abstract}

Key words: rural emigration, return, Ireland

\section{Résumé}

Cet article a pour but de contribuer à une meilleure compréhension de l'émigration internationale et du retour dans les espaces rurales en utilisant des données provenant d'Irlande. Le document présente des concepts clés relatifs à l'émigration des espaces rurales et au retour vers ces espaces. Les résultats des entretiens avec quarante-six migrants de retour, qui étaient interviewés en 2011 et 2013, sont ensuite discutés. Tous les émigrants ont passé au moins un an à l'étranger et ont passé au moins une année en Irlande après leur retour. Les observations révèlent l'influence continue des facteurs économiques et sociaux sur l'émigration. La migration et l'accès à l'emploi ont été facilités par la famille et les amis à l'étranger, parmi les moins qualifiés, tandis que les plus qualifiés ont utilisé les agences et les annonces. La plupart des migrants vivaient dans des cadres transnationaux ; ils ont maintenu un contact régulier avec leur famille à la maison et beaucoup ont visité l'Irlande au moins une fois par an. Ces contacts ont servi de sources d'information pour les opportunités en Irlande. La plupart ont retrouvé un emploi; cependant, la réunion avec la famille était une motivation clef pour le retour couplée aux souvenirs d'une campagne idyllique. L'expérience suivant le retour n'a pas toujours répondu aux attentes et certains rapatriés ont de nouveau émigré.

Mots-clés : l'émigration des zones rurales, retour, Irlande.

\section{Introduction}

Emigration overseas, the subject of this article, is one form of migration. Migration per se is subject to many different definitions in terms of its meaning, the scale at which it takes place and the 
time period involved (BARCUS \& HALFACREE, 2018). Migration is usually interpreted as referring to a change of residence but this can be at a local, regional, national or international scale. In the past, emigration overseas tended to be viewed as a permanent or long-term move, although a 'myth of return' was known to exist, even if the myth was not attained (ANWAR, 1999). Shorter-term movement, referred to as 'mobility', is also increasing because of lowered travel costs and increased access to information about employment opportunities through the internet (SHELLER \& URRY, 2006). This chapter adopts the internationally-accepted definition of migration as involving a change of residence of at least one year's duration (EC, 2018). Migration takes place for many different reasons, including education, employment, stage in the family life cycle and retirement. This article is concerned particularly with labour-related emigration overseas from rural areas by adults who make personal decisions to leave and return at a later stage. Nowadays that return is usually anticipated and the period of absence may be known in advance, especially if regulated by a work permit. The research is based on interviews, conducted in 2011 and 2013, with a sample of forty-six returnees to rural Ireland (the Republic of Ireland) who spent at least one year living outside the island of Ireland and who spent at least one year resident in rural Ireland again following their return, before being interviewed. The majority were labour migrants but the sample also included students who emigrated for educational purposes. A small number had emigrated again and were interviewed by Skype. Rural areas are defined according to the Irish census of population definition as being places with a population of less than 1500 people and include small towns, villages and the open countryside. The article consists of the following: a review of key concepts relating to labour migration; discussion of rural emigration and return; the geographical context of Ireland; the data sources and analysis; the findings; and a discussion and conclusions.

\section{Concepts}

The explanation of labour migration nationally and internationally has attracted extensive research attention from economists, geographers, sociologists and anthropologists from different disciplinary perspectives (BRETTELL \& HOLLIFIELD, 2008). It is not the purpose of this paper to review the extensive body of literature that exists. Instead, a number of the main explanations for labour migration, including emigration overseas, from and return to rural areas will be referred to. Traditional macroeconomic explanations, based usually on official data sources, draw on neoclassical economics to explain movement from low wage to higher wage locations (GREENWOOD, 1985; MASSEY et al., 1993; TODARO, 1969). SJAASTAD (1962) introduced a micro-economic perspective at an early stage in proposing that individuals weigh up the costs of moving as against the perceived benefits that might be expected to result in their decision making. In the neoclassical model, return to the place of origin is viewed as a failure of the migrant to maximise on the opportunities provided in the new destination to increase income and achieve permanent settlement (CASTLES et al., 2014). The new economics of labour migration (NELM), associated with the work of STARK (1991) and STARK \& BLUM (1985) recognises the role of families and households in migration decision-making. The NELM is based on evidence for developing countries, in particular, where people move in order to 
remit funds for family support and/or accumulate funds for investment in household improvements and/or a business on a planned future return. It may be encouraged by the government in the country of origin and its duration is usually influenced by migration policy in the destination country (RUIZ, 2008). In the NELM, return is part of migration planning, instead of being a sign of failure. More generally, it is recognised that the national and international mobility of professional, managerial, skilled, semi-skilled and unskilled workers, for periods of less than one year, is increasing (SHELLER \& URRY, 2006). The concept of '(e)migration' as a long-term or permanent move, as conceived in the neoclassical model, is therefore questioned.

Whilst economists have recognised the role of individual migration decision-making, much of the research in this context is conducted by geographers, sociologists and anthropologists based on qualitative studies. Such humanistic studies sometimes adopt a longitudinal approach following the migrant over part of the life course from migration to return (e.g., Ni LAOIRE, 2008). BARCUS \& HALFACREE $(2018,117)$ identify the merits of adopting a biographical approach to the study of migration as "a life course expression". They say that a biographical approach is not limited to the individual migrant but includes the role of the family in influencing the individual biography and extends beyond migration per se (ibid.,119). National and international migration is recognised as being 'path-dependent' in that it becomes part of the culture of particular families and groups and may take place between clearly defined geographical areas (BOYD, 1989; BOYLE \& HALFACREE, 1998). BOYLE and HALFACREE (1998) refer to 'cultures of migration' whereby migration appears as an integral aspect of the way of life of particular groups. Emigration overseas has for long been part of Irish culture. It has taken place particularly, but not exclusively, from rural areas, because of the inability of the employment base locally or nationally to absorb the natural increase in population. Return migration has also taken place, especially during periods of economic recovery (PUNCH \& FINNERAN, 1999).

International emigration has always had certain transnational dimensions, in that links were retained with the country of origin through correspondence, initially, then telephone and, more recently, advanced information and communication technologies (ICTs) (LEVITT et al., 2003). The types, intensity and frequency of links have increased with advances in ICTs and the reduced costs of international travel. Return visits on holiday have become more usual, even from distant destinations, as the costs of international travel have declined. Visits by family to emigrants overseas have increased. Emigrants may also engage in business activities between their area of origin and the migration destination, in serving ethnic markets or as part of international business relationships (LEY, 2009). Some emigrants and emigrant groups engage in transnationalism, as expressed in continued active involvement in political activities in their country of origin (GUARNIZO et al., 2003). Transnational practices are therefore being recognised increasingly as features of international migration. They have important implications as sources of information about employment opportunities overseas, may provide accommodation and other supports on arrival and later serve as channels of information about employment opportunities in the area of origin (BOYD, 1989). Such links with family and friends conform to GRANOVETTER'S (1973) concept of 'strong ties', by contrast with the 'weak 
ties' of agencies and advertisements associated with more formal sourcing of employment. Transnational links influence both emigration and return (CONWAY \& POTTER, 2006).

\section{Rural to urban emigration and return}

Notwithstanding urban to rural residential migration since the 1970s, as part of counterurbanisation trends, rural to urban migration continues within and between countries arising from the restructuring of agricultural and other natural resource systems and the absence of adequate sources of alternative employment to absorb the demand that exists (STOCKDALE, 2004). Rural to urban migration within countries is associated also with progression to post-secondary education and the limited opportunities that exist for third level graduates in their areas of origin (THISSEN et al., 2010). Rural to urban migration takes place overseas as part of EU Erasmus and Socrates programmes and to access specialist courses (TEICHLER, 2004). Only a small proportion of graduates can expect to return to live and work in a rural area. Apart from the quest for employment, urban areas are known to exert an appeal for young people in search of personal freedom as they move into adulthood and seek self-realization (ARNETT, 2000). The urban is perceived as a place of possibilities, economically and personally. This paper is concerned in particular with emigration from rural areas in one country to large city environments in other countries in search of employment. This phenomenon is not confined to Ireland, as the history of migration from Europe to the US illustrates, but it is a distinctive feature. Research on rural emigrants in urban areas has traditionally focused on their tendency to live in close proximity with, often, people from particular areas clustering together in a form of translocalism (LEY, 2009). Nevertheless, feelings of disorientation caused by being in an unfamiliar cultural space while abroad have been documented (AHMED, 1999).

Return from urban areas to rural areas of origin has received increased attention during the last three decades (KING, 1986). The ideotope of place and its influence on the migrant is discussed by PASCUAL de SANS (2014). MORSE (2018) has recently documented the emotional pull of the rural area of origin and particularly its scenic qualities among highly educated international return emigrants to the state of Vermont in the USA. Desires to live near family, to raise children in one's home area, to live in a small community, and to feel a sense of belonging have been identified as factors in rural return migration to Ireland (CAWLEY \& GALVIN, 2016; Ní LAOIRE, 2007), the United Kingdom (HOLMES \& BURROWS, 2012), and the United States (von REICHERT et al., 2014).

Whilst an idyllic memory of the countryside may influence the decision to return, the experience following return can have negative dimensions. Returnees have changed as a result of their overseas experiences. The places and populations they return to may have changed also. Nevertheless, the constraints on economic well-being and standards of living that influenced emigration in the first instance often persist. It may be necessary to readapt in unanticipated ways. 


\section{Geographical context: Ireland}

Ireland has a long history of emigration from rural areas to cities in the State but especially to overseas cities in Britain, the United States (US), Canada and Australia, since the Great Famine in the mid-nineteenth century (Mac LOUGHLIN, 1994). Because of the small size of the national economy and the national space, emigration overseas has continued to serve as a pathway to employment and self-fulfilment and a control on unemployment (GLYNN et al., 2014; PUNCH \& FINNERAN, 1999). Currently (2019), there is free movement between Ireland and Britain which are effectively one labour market; the implications of Britain's withdrawing from membership of the EU for migration between the two countries remain to be seen. Emigration to the US, Canada and Australia has varied over time, in line with their immigration policies, and has become more difficult in recent decades (GLYNN et al., 2014). Currently, most movement to these countries takes place through short-term work permits. Joining the then EEC, in 1973, opened up new migration opportunities for Irish people, particularly after the Maastricht Treaty established the EU in 1992 and introduced the principle of European citizenship. Ireland has a long history of emigration of Christian missionaries to countries of Asia and Africa. Missionary migration has declined numerically but emigration of workers employed by aid agencies has increased in recent decades (INGLIS, 2008). These various overseas movements have included people of rural as well as urban origin.

Whilst emigration from Ireland has been highlighted in the academic literature, because of its scale and role in controlling population numbers, return migration has taken place also (CORCORAN, 2002; GMELCH, 1986; PUNCH \& FINNERAN, 1999). Return to rural areas has received some research attention. The role of life course events, connections with family and recollections of an idyllic countryside are discussed by Ní LAOIRE (2007) and, more recently, by CAWLEY \& GALVIN (2016). Links with entrepreneurship are identified (CAWLEY, 2015; Mc GRATH, 1991). Apart from Mc GRATH (1991) and CAWLEY (2015) few studies focus specifically on migrants who moved from and returned to a place with less than 1500 residents. This study discusses information relating to such a group.

\section{Data sources and analysis}

This article is based on personal interviews with forty-six returned emigrants, who migrated and returned between 1947 and 2010 to a place of less than 1500 population, defined as 'aggregate rural areas' in the Irish census of population (Table 1). All emigrated from the Rol, spent at least one year resident overseas, primarily in Britain (75\%), the US (17\%) and Australia (6\%), in a major city which included London, New York and Sydney. All visited whilst away, maintained regular contact with family and friends at home and with compatriots abroad and were resident again in the State for one year or more when interviewed. Some, primarily recent, emigrants and those migrating for educational purposes, returned several times annually. The periods of time spent away varied from one to 48 years, with an average of 11 , a mode of 3 and a median of 7 years. The interview data were obtained from a sample sourced through university geography students who were studying migration as an 
academic module, a recognised valid source of information (FORTUIJN \& VAN DER MEER, 2006). The interviewees included grandparents, parents, aunts, uncles and siblings, providing information for a long time period. A structured interview schedule with closed and open questions was developed by the author and given, in February 2011 and 2013, to the students and detailed instructions were provided in a lecture and a workshop about the conduct of the interview and the recording of the information. The data were entered into a database and transferred to SPSS $\AA^{\circ}$ to tabulate the quantitative variables. Extensive iterative qualitative data analysis was conducted on the text from the open questions to identify key themes and sub-themes and relate them to the personal characteristics of the respondents (BRYMAN, 2008).

Although the numbers are small, broad relationships may be identified between the periods of emigration and return and the state of the Irish economy (Table 1). Emigration was relatively higher prior to the 1970s and between 1971 and 1990 which included periods of recurring recession. Return exceeded emigration between 1991 and 2007 which covered a period of marked economic growth in Ireland (OECD, 2010). It is interesting to note that although emigration increased following the recession of 2008 return migration also increased as the economy began to recover after 2011 . This has been attributed, in part, to the capacity of former emigrants (and their families) to return from Britain in response to an upturn in the economy (LUNN, 2012).

Table 1: Sample distribution by period of emigration and return (\%) $(n=46)$

\begin{tabular}{|l|l|l|}
\hline Time period & Emigration (\%) & Return (\%) \\
\hline Pre-1971 & 26.1 & 13.0 \\
\hline $1971-1990$ & 39.1 & 21.7 \\
\hline $1991-2000$ & 4.3 & 21.7 \\
\hline $2001-2007$ & 6.5 & 17.4 \\
\hline 2008 on & 24.0 & 26.2 \\
\hline
\end{tabular}

The sample contained more males than females $(63.0 \%$ versus $37.0 \%)$, whereas the malefemale ratio among returnees in the census of 2011 is more evenly balanced. The higher return of males than of females to rural areas is explicable partly because of recovery in the construction industry which is a source of male employment primarily (LUNN, 2012). Some females in the sample who left rural areas returned to towns with a population of 1500 or more and are not included in the analysis.

\section{Findings}

The profile of the emigrants in terms of age and conjugal status conforms to a pattern of emigration in the late teens and early twenties when people have greater freedom of movement before they undertake family commitments (SJAASTAD, 1962) (Table 2). Human capital levels were 
relatively high as indicated by the education levels attained; a majority of both males and females held a secondary level (high school) or third level education (university or institute of technology). More males than females emigrated with a primary education only, before access to second level education became freely available in Ireland in 1967. Emigration took place from employment and from unemployment. The reasons cited by the employed migrants revealed that they were in jobs below their level of qualification which they found unsatisfactory and which offered few opportunities for advancement, reflecting other Irish research (SEXTON et al., 1991; GLYNN et al., 2014). Such features point to the limited opportunities available in rural areas in general and, more specifically, during periods of recession. Small numbers of males and females emigrated to obtain higher education qualifications in specialist disciplines or because they did not qualify for a course in Ireland.

Table 2. Socio-economic characteristics of sample at time of emigration

\begin{tabular}{|l|l|l|}
\hline Age & Male $(\mathbf{n}=\mathbf{2 9})$ & Female $(\mathbf{n}=\mathbf{1 7})$ \\
\hline$\leq 20$ years & 48.3 & 53.0 \\
\hline $21-24$ & 38.0 & 29.4 \\
\hline $25-29$ & 10.3 & 17.6 \\
\hline $30+$ & 3.4 & - \\
\hline Conjugal Status & & \\
\hline Single & 72.4 & 82.4 \\
\hline Married/partner & 27.6 & 17.6 \\
\hline Education & & \\
\hline Primary & 27.6 & 5.9 \\
\hline Secondary & 38.0 & 70.6 \\
\hline Third level & 24.1 & 23.5 \\
\hline Postgraduate & 6.9 & - \\
\hline Other & 3.4 & - \\
\hline
\end{tabular}

Source: survey data from 2011 and 2013

The respondents were asked an open question about their reasons for emigrating and returning which they were requested to list in order of importance; the reasons were not suggested to them. During the analysis, a ranking was conducted based on all of the responses (Table 3). Most respondents mentioned several factors as influencing their decision to emigrate. Not surprisingly, given their employment profile, being unemployed and seeking work was the first reason cited, followed by wishing to gain a better job or experience that would improve their employment prospects in the future (Table 3). Life style factors had a role for some in terms of wishing to travel and experience other cultures; this motivation was expressed especially during the years of economic growth when the respondents felt that they would be able to obtain employment on their return to Ireland after spending a year or two working overseas. Motivations that relate to personal fulfilment through gaining independence from family were cited also.

Because of a history of emigration overseas, many Irish people have a network of personal connections in major international cities which contribute to a path-dependent culture of migration. 'Strong ties' with relatives and friends overseas were mentioned by skilled and semi-skilled emigrants to Britain, in particular, as sources of information about employment opportunities and sources of 
support on arrival (GRANOVETTER, 1973). Longer-distance emigrants to Australia and the professionally qualified were more likely to use the 'weak ties' of formal sources of information such as agencies and advertisements. Socialising with other Irish people overseas in pubs or bars, Irish clubs and playing sports was the norm and must have provided social and psychological support. All of the interviewees had visited their home area at least once whilst away and most did so at least once annually. They were also in regular contact with parents and siblings in Ireland using media that had changed over time from letters to texting, Skype and Facebook. These various connections with people in Ireland were sources of information about employment opportunities which may have influenced the decision to return and the timing of return.

Table 3. Reasons cited for emigration and return in order of importance

\begin{tabular}{|l|l|}
\hline Reasons for emigration & Rank \\
\hline Unemployed/seeking work & 1 \\
\hline Gain experience/a better job & 2 \\
\hline 'See the world', 'travel', independence & 3 \\
\hline Reasons for return & \\
\hline Missed family and friends & 1 \\
\hline Raise/educate children in Ireland & 2 \\
\hline Employment opportunity available & 3 \\
\hline Family obligations & 4 \\
\hline Finished an educational course & 5 \\
\hline Retirement & 6 \\
\hline
\end{tabular}

Although regular contact was reported with Irish people overseas, the move from the countryside to a large city posed certain challenges which emerged when the respondent was asked about differences from the place of origin. In particular the loss of the sense of being known, which is associated with a small community, as documented by Ní LAOIRE (2007), and the loss of a green landscape were referred to. Recapturing these features emerged in the reasons for return. A woman who emigrated in 1954 to Leeds, England, aged 19 (and returned in 1974 with her family), valued the superior city services, but said: "It was not home... so many strange faces. When at home, you always knew someone and a friendlier face". A man who moved to London, aged 20, in 1982, experienced: "no real sense of community in towns and cities compared to a small village". The contrast in the physical environment was highlighted by a man who moved to Boston in 1994, aged 24 (and returned, in 2004, with his partner before the birth of their second child): "Boston was like a concrete jungle compared with (place of origin's) green". He also missed the Irish practice of casual conversation: "(I) missed the chat (talk) from Ireland as (in the) USA (it) was a very fake chat as people were un-friendly unless they wanted something".

The reasons for return prioritised social factors over the economic, as JONES (2003) observed in earlier Irish research, although the capacity to return in most cases depended on access to employment, possession of financial capital (among retirees) or inheritance of property (Table 3). 'Missed family and friends' was the first reason cited for return, which CORCORAN (2002) described 
as a search for 'anchorage' among US returnees. The influence of stage in the life course was also strong, notably planning a family, the birth of a child or a child or children starting school. At these stages some emigrants began to consider the advantages of proximity to family and education in Ireland, in comparison with the city environment where they then lived. A woman who returned from London, aged 30, in 2011, gave her reasons as being "a desire to settle down and start a family with (my) partner away from the hustle and bustle of city life". A 41 year-old man who returned, from New York, with his spouse and children in 2000, to a small town, cited "the education of (the) children" and (A) better growing up process in Ireland", than in New York, as primary motives. Acquisition of the Irish language was referred to by a 32 year-old woman from the Gaeltacht (where Irish is the first spoken language and the medium of instruction in schools) who returned in 1993. A small number of people returned to take care of elderly parents or take over the running of a farm (family reasons) (Table 3). Two people who returned on retirement cited closeness to family as a main motivation. Students returned on completing an education course, without necessarily having employment arranged, some of whom emigrated again and returned again, as in the following example. A student who moved to England in 2003 to pursue a degree course, returned on graduation, in 2006, and left again in 2007 with friends for "travel and adventure". She travelled in Southeast Asia, worked in a number of different jobs in Australia, and returned in 2009 to join her partner, who had returned already.

Closeness to family was also mentioned first in response to a question about what was enjoyed most about having returned to live in Ireland. Several people also referred to the advantages of living again in a rural environment, reflecting features of life that they missed whilst overseas. One respondent, who emigrated in 1947, aged 17, and returned with his wife and family in 1970, cited what he enjoyed most on return as: "A peaceful life and being with friends and family". Another man who migrated in 1987 as an unskilled labourer and returned in 1999, because employment was available, also valued closeness to family and a return to the countryside: "back to family roots; coming back to rural Ireland- freedom and fresh air". A 35 year old woman who returned from New York to care for her ill father, in 2000, referred to a sense of disjuncture in not being an insider or an outsider, but valued the "peaceful life, slow-paced; family; old friends and familiar surroundings".

The experience of living in Ireland again following return was queried. There was an initial euphoria in being close to family and friends again, as discussed above. Some of the realities of rural life such as poor levels of public transport and service provision, which contrasted markedly with life in a city, were found difficult, particularly by women, as GMELCH (1986) found some three decades ago. The woman who wished to escape the 'hustle and bustle' of city life, cited above, identified challenges associated living in the countryside again: "Re- adapting to the slow pace of life and lack of facilities in the countryside. Leaving behind the good friends we made in the UK". A 29 year-old man who returned from Bedford in England in 1966, to take care of the family farm, found life in his area of origin "lonely and quiet". A woman who returned from London with her spouse and children, in 1996, to a village some $30 \mathrm{Km}$ from her area of origin, said that there were difficulties in "Getting to know people in the community and leaving friends behind".

Corroborating Ní LAOIRE's (2008) findings, some younger returnees found rural life dull in comparison with a city and experienced a lack of privacy in small communities (the obverse of the 
anomie which they had experienced in a city). Some discovered that many of their friends had emigrated. A young man who returned in 2011 to attend university, having spent three years away, said that: "Most people of (the) same age had moved away, (the) area was quiet, even less jobs than when I left". Similarly, a 21 year old nurse who returned from London in 2012, referred to "the boredom, lack of activities...loss of independence... loss of private life".

The sample included repeat migrants, who are under-studied in Ireland. Eight returnees emigrated again (five of whom returned a second time), pointing to the growing occurrence of shorterterm migration and mobility. They included young people who wished to travel, as in the case of the female discussed earlier who travelled to Southeast Asia on completing her degree in the UK. Others, although having employment, missed city life and returned for a number of years to a city where they had worked or studied. One family returned to a US city, in 1997, to obtain special medical care for a child.

\section{Discussion and conclusions}

Economic factors have long been identified as reasons for rural to urban migration nationally and internationally and remain influential (CASTLES et al., 2014). During the last two decades, geographers, in particular, have advocated the merits of adopting a life course approach to the study of migration and emigration and of moving 'beyond the economic' (HALFACREE, 2004). Personal narratives have been given attention as a method of gaining additional insights into the influences involved (Ní LAOIRE, 2007). The reported research adopted a biographical approach to the study of emigration and return among returnees in rural villages and open countryside in Ireland. The sample covers a longer period of time than do most earlier studies and has a specific focus on small rural areas. The findings reveal broad commonalities over time in the reasons for emigration, the experience overseas, the reasons for returning and the experience following return. These findings corroborate several findings of earlier research but also highlight the transnational contexts in which emigration and return take place (LEVITT et al., 2003). The evidence shows that economic motives underpin a decision to emigrate but that social factors are also involved in impelling young people to leave rural areas which provide limited opportunities for personal fulfilment more generally, as in the Netherlands (THISSEN et al., 2010). Their migration is facilitated by transnational connections arising from previous emigration streams. For the most part, they move to areas where Irish 'communities' exist which provide social and psychological support (WALTER, 1980). However, a remembered home environment surrounded by family and friends is missed and a more critical perspective emerges on a city environment as a place to bring up children. A city school is also perceived, by some parents, as providing a less positive educational experience for children than their remembered schooling in Ireland. These factors influence the decision to return, if economic circumstances permit. The experience following return does not always meet the memory, as the realities of rural living, which may have been overlooked during holiday visits, intrude (GMELCH, 1986; Ní Laoire, 2008). Nevertheless, people with children, who have found employment and usually invested in housing, adapt for the most part. Younger returnees may find rural realities less acceptable and use their 
transnational experience and connections to emigrate again. There is therefore evidence of shorterterm migration and mobility.

Return migration across the life course brings human, social and economic capital to rural areas. Rural communities benefit through increased numbers of children attending primary schools and using local services (CAWLEY, 2015). Returnees bring skills and experience gained overseas and should be supported further by development agencies. Local communities also need to be more receptive of returnees who, in turn, must be able to reconcile the remembered idyll with the lived rurality. The present study documented broad features of migration and return over a substantial period of time in rural Ireland. This approach contributes to understanding of migration and return. More detailed research is required on different age-cohorts and occupational groups of returnees and potential returnees as inputs to rural policy design to attract emigrants back.

\section{References}

AHMED, S. (1999). Home and away: narratives of migration and estrangement. International Journal of Cultural Studies, 2(3), 329-347.

ANWAR, M. (1979). The myth of return. London: Heinemann.

ARNETT, J. (2000). Emerging adulthood: a theory of development from the late teens through the twenties. American Psychologist, 55(5), 469-480.

BARCUS, H.B. \& HALFACREE, K. (2018). An introduction to population geography: lives across space. Abingdon: Routledge.

BOYD, M. (1989). Family and personal networks in international migration. International Migration

Review, 23(3), 638-670.

BOYLE, P. \& HALFACREE, K. (Eds.) (1998). Migration into rural areas: theories and issues. Chichester: Wiley.

BRETTELL, C.B. \& HOLLIFIELD, J.F. (Eds.) (2008). Migration theory: talking across disciplines (2 ${ }^{\text {nd }}$ ed.). London: Routledge.

BRYMAN, A. (2008). Social research methods. Oxford: Oxford University Press. CASTLES, S., de Haas, H., \& MILLER, M.J. (2014). The age of Migration ( $5^{\text {th }}$ ed.). London: Palgrave Macmillan.

CAWLEY, M. (2015). International return migration and rural sustainability: Irish evidence. Carpathian Journal of Earth and Environmental Sciences, 10(3), 15-24.

CAWLEY, M. \& GALVIN, S. (2016). Irish migration and return: continuities and changes over time. Irish Geography, 49(1), 11-27.

CONWAY, D. \& POTTER, R.B. (2006) Caribbean transnational return migrants as agents of change. Geography Compass, 1, 1-21.

CORCORAN, M. (2002). The process of reinvention of self: returning Irish migrants. Éire-Ireland, 37(1-2), 175-191.

de BREE, J., DAVIDS, T., \& de HAAS, H. (2010). Post-return experiences and transnational belonging of return migrants: a Dutch-Moroccan case study. Global Networks, 10(4), 489-509.

EC (European Commission) (2018). Eurostat Statistics Explained, accessible at: http://ec.europa.eu/eurostat/statistics-explained/index.php/Glossary [accessed 27 July 2018\}.

FORTUIJN, J.D. \& van der MEER, M. (2006). Gender and voluntary work in late adulthood in rural communities in the Netherlands. GeoJournal, 65, 381-392.

GLYNN, I., KELLY, T. \& MacENRÍ, P. (2014). Irish emigration in an age of austerity. Cork: Emigré Project University College Cork.

GMELCH, G. (1986). The readjustment of return migrants in western Ireland. In R. King (Ed.), Return migration and regional economic problems (pp. 152-170). London: Croom Helm. 
GRANOVETTER, M. (1973). The strength of weak ties. American Journal of Sociology, 78(6), 13601380.

GREENWOOD, M.J. (1985). Human migration: theory, models, and empirical studies. Journal of Regional Science, 25(4), 521-544.

GUARNIZO, L.E., PORTES, L. \& HALLER, W. (2003). Assimilation and transnationalism: determinants of transnational political action among contemporary migrants. American Journal of Sociology, 108(6), 1211-48.

HALFACREE, K. (2004). A utopian imagination in migration's terra incognita? Acknowledging the noneconomic worlds of migration decision-making. Population, Space and Place, 10, 239-253.

HOLMES, M. \& BURROWS, R. (2012). Ping-pong poms: emotional reflexivity in contemporary return migration from Australia to the United Kingdom. Australian Journal of Social Issues, 47(1), 105113.

INGLIS, T. (2008). Global Irish: same difference. London: Routledge.

JONES, R.C. (2003). Multinational investment and return migration in the 1990s: county-level analysis. Irish Geography, 36(2), 153-169.

KING, R. (1986). Return migration and regional economic development: a review. In R. KING (Ed.), Return migration and regional economic problems (pp. 1-37). London: Croom Helm.

LEVITT, P., DeWIND, J., \& VERTOVEC, S. (2003). International perspectives on transnational migration: an introduction. International Migration Review, 37(3), 565-575.

LEY, D. (2009). Transnationalism. In R. KITCHIN \& N. THRIFT (Eds.), The international encyclopaedia of human geography (pp. 388-393). London: Elsevier.

LUNN, P. (2012). The impact of recession on migration: a preliminary analysis of census 2011, research notes. In D. DUFFY, D. DURKAN, \& E. CASEY (Eds.), Quarterly economic commentary (pp. 1-12). Dublin: Economic and Social Research Institute.

Mac LOUGHLIN, J. (1994). Ireland: the emigrant nursery and the world economy. Cork: Cork University Press.

MASSEY, D.S., ARANGO, J., HUGO, G., KOUAOUCI, A., PELLEGRINO, A., \& TAYLOR, J.E. (1993). Theories of international migration: a review and appraisal. Population and Development Review, 19(3), 431-466.

Mc GRATH, F. (1991). The economic, social and cultural impacts of return migration to Achill Island. In R. KING (Ed.), Contemporary Irish migration, Geographical Society of Ireland special publication no. 6 (pp. 55-69). Dublin: Trinity College.

MORSE, C. (2018). The emotional geographies of global return migration to Vermont. Emotion, Space and Society, 25, 14-21.

Ni LAOIRE, C. (2007). The 'green green grass of home'? Return migration to rural Ireland. Journal of Rural Studies, 23(3), 332-344.

Ní LAOIRE, C. (2008). 'Settling back'? A biographical and life-course perspective on Ireland's recent return migration. Irish Geography, 41(2), 195-201.

OECD (Organisation for Economic Cooperation and Development) (2010). Economic outlook 2010 OECD: Paris.

PASCUAL-de-SANS, A. (2004). Sense of place and migration histories: idiotopy and idiotope. Area 36(4), 348-357.

PUNCH, A. \& FINNERAN, C. (1999). The demographic and socio-economic characteristics of migrants, 1986-1996. Journal of the Statistical and Social Inquiry Society of Ireland, 28(1), 213263.

RUIZ, N.G. (2008). Managing migration: lessons from the Philippines. Migration and Development Brief 6. Washington DC: World Bank. Accessible at: http://neilruiz.org/wpcontent/uploads/2015/07/MD Brief6.pdf [accessed on 
RYE, J. (2006). Rural youths' images of the rural. Journal of Rural Studies, 22(4), 409-421.

SEXTON, J.J., WALSH, B.M., HANNAN, D.F. \& McMAHON, D. (1991). The Economic and Social Implications of Emigration, Report No. 90. Dublin: National Economic and Social Council.

SHELLER, M. \& URRY, J. (2006). The new mobilities paradigm. Environment and Planning A, 38, 207-226.

SJAASTAD, L.A. (1962). The costs and returns of human migration. The Journal of Political Economy, 70 (5ii), 80-93.

STARK, O. (1991). The migration of labour. Oxford: Blackwell.

STARK, O. \& BLUM, D. (1985). The new economics of labour migration. American Economic Review, 75(2), 173-78.

STOCKDALE, A. (2004). Rural out-migration: community consequences and individual migrant experiences. Sociologia Ruralis, 44(2), 167-194.

TEICHLER, U. (2004). The changing debate on internationalisation of Higher Education. Higher Education, 48, 526.

THISSEN, F., DROOGLEEVER, J., STRIJKER, D., HAARTSEN, T. (2010). Migration intentions of rural youth in the Westhoek, Flanders Belgium and the Veenkoloniën, The Netherlands. Journal of Rural Studies, 26, 432-436.

TODARO, M. P. (1969). A model of labour migration and urban unemployment in less-developed countries. The American Economic Review, 59, 138-48.

von REICHERT, C., CROMARTIE, J., \& ARTHUN, R. (2014). Reasons for returning and not returning to rural US communities. Professional Geographer, 66(1), 58-72.

WALTER, B. (1980). Time-space patterns of second wave Irish immigration into British towns. Transactions of the Institute of British Geographers, New Series 5(3), 297-317.

\section{ACKNOWLEDGEMENTS:}

I am grateful to the students who conducted the interviews and to Dr Stephen Galvin who collated the students' data entries and conducted an initial analysis of the numeric data. 